\title{
GATZ, Erwin, Die Bistümer des Heiligen Römischen Reiches von ihren Anfängen bis zur Säkularisation
}

\section{Christophe Duhamelle}

\section{OpenEdition \\ Journals}

Édition électronique

URL : http://journals.openedition.org/ifha/916

DOI : 10.4000/ifha.916

ISSN : 2198-8943

Éditeur

IFRA - Institut franco-allemand (sciences historiques et sociales)

Référence électronique

Christophe Duhamelle, « GATZ, Erwin, Die Bistümer des Heiligen Römischen Reiches von ihren Anfängen bis zur Säkularisation », Revue de l'IFHA [En ligne], Date de recension, mis en ligne le 01 janvier 2004, consulté le 22 septembre 2020. URL : http://journals.openedition.org/ifha/916 ; DOI : https://doi.org/ 10.4000/ifha.916

Ce document a été généré automatiquement le 22 septembre 2020.

(C)IFHA 


\title{
GATZ, Erwin, Die Bistümer des Heiligen Römischen Reiches von ihren Anfängen bis zur Säkularisation
}

\author{
Christophe Duhamelle
}

1 Présidant depuis près de 30 ans aux destinées du Campo Santo Teutonico, directeur de l'institut romain de la Görres-Gesellschaft, animateur de la Römische Quartalschrift (voir BullMHFA, 37, 2001, p. 91), E.G. est une figure de proue de l'histoire ecclésiastique catholique mais aussi un historien soucieux de faire naître des instruments de travail systématiques et précieux. C'est lui qui présida à l'élaboration du dictionnaire biographique des évêques du Saint-Empire entre 1198 et 1945 et assura de 1983 à 2001 la direction des quatre tomes (BullMHFA, 23, 1991, p. 103-106 ; BullMHFA, 34, 1998, p. 298) que compte cette somme désormais incontournable. Le présent dictionnaire des évêchés s'inscrit dans la lignée de cette entreprise, jusque dans le format et la présentation, similaires, alors même que l'éditeur a changé. Il doit en outre comprendre un second volume, prévu pour 2004, et couvrant la période postérieure aux sécularisations de 1803.

2 Cette entreprise de synthèse sur l'Église d'Empire a donc ici choisi comme critère organisateur non plus les dignitaires, mais les ressorts. À l'exception de deux fondations peu durables de saint Boniface (Erfurt et Büraburg) et des évêchés créés à la fin du XVIIIe s. dans les États des Habsbourg (qui seront traités dans le second volume), une notice est consacrée à chacun des 77 évêchés qui ont existé des origines à 1803 dans un Saint-Empire compris au sens le plus large (anciens territoires de l'Ordre Teutonique inclus), ainsi qu'aux " missions du Nord » de l'ère confessionnelle. 78 articles en tout, donc, dont la longueur, en fonction de l'état des connaissances, de l'importance du siège et de sa durée de vie, fluctue entre 2 et 26 pages et dont chacun est suivi d'une liste des évêques et d'indications bibliographiques elles aussi à géométrie variable (de deux pages à... trois titres pour la notice la plus longue, Mayence). Les articles rassemblent les informations principales sur la fondation, les variations d'étendue, la mise en place des structures ecclésiastiques, mais aussi 
l'inscription de chaque évêché dans la vie politique de l'Empire, puisqu'à la plupart des diocèses fut associé un pouvoir séculier s'étendant d'ailleurs sur une zone géographique (le Hochstift, ou l'électorat pour les trois archevêques de Mayence, Cologne et Trèves) différente du ressort ecclésiastique. La partie cartographique finale, très précieuse, distingue autour de 1500 les deux types d'espace. Il est sans doute inutile de souligner l'intérêt de cet ouvrage que toute bibliothèque se doit de posséder, et dont la solidité matérielle préfigure le nombre de fois où on le prendra en mains.

Christophe DUHAMELLE (MHFA) 